\title{
THE FUNCTION OF NGENTEG LINGGIH CEREMONY IN PEJATEN TABANAN
}

\author{
Ida Ayu Tary Puspa ${ }^{1}$, Ida Bagus Subrahmaniam Saitya ${ }^{2}$ \\ ${ }^{12}$ Universitas Hindu Negeri I Gusti Bagus Sugriwa Denpasar \\ ${ }^{1}$ tarypuspa@uhnsugriwa.ac.id, ${ }^{2}$ tugusbramsaitya@uhnsugriwa.ac.id
}

\begin{abstract}
The Dewa Yajña Ceremony is a ceremony addressed to Ida Sang Hyang Widhi with all of His manifestations as a form of devotion because He has created the universe and everything in it. This gratitude was manifested by the people of Pejaten Village by holding a ceremony to instill the Creator to rest in the sacred temple building. The Ngenteg Linggih ceremony has functions such as religious, ethics, aesthetics, and social. Each of these functions is related to one another which of course will play a role in the ceremony. Such as a religious function in which the ceremony provides a basis for belief in the community through the rites and ritual equipment to convince the public that through the ceremony carried out, religious emotions will grow. The function of ethics is to provide guidance in living through the Ngenteg Linggih ceremony to always live life by thinking, saying, and doing good according to what you are doing in your ceremony. The aesthetic function provides beauty as well as truth and sanctity so that people feel the beauty in regulating life practices as outlined in the means and implementation of the ceremony. The social function is shown by the community who work together hand in hand to load the ceremony and carry it out with the concept of ngayah.
\end{abstract}

\section{Keywords: Function; The Ceremony of Ngenteg Linggih}

\begin{abstract}
Abstrak
Upacara Dewa Yajña adalah upacara yang ditujukan kepada Ida Sang Hyang Widhi dengan segala manifestasi-Nya sebagai wujud bhakti karena Beliau yang sudah menciptakan alam semesta beserta segala isinya. Ucap syukur tersebut diwujudkan oleh masyarakat Desa Pejaten dengan menyelenggarakan upacara untuk menstanakan Sang Pencipta agar berstana pada bangunan suci Pura. Upacara Ngenteg Linggih tersebut memiliki fungsi seperti religious, etika, estetika, dan social. Masing-masing fungsi tersebut berkaitan satu sama lainyang tentunya akan berperan dalam upacara tersebut. Seperti fungsi religious yang mana upacara tersebut memberi dasar keyakinan kepada masyarakat enelalui ritus dan peralatan ritusnya untuk dapat meyakinkan masyarakat bahwa melalui upacara yang dilaksanakan akan dapat menumbuhkan emosi keagamaan. Fungsi etika memberi tuntunan dalam berkehidupan melalui upacara Ngenteg Linggih untuk selalu menjalankan hidup dengan berpikir, berkata, dan berbuat yang baik sesuai sesana dalam berupacara. Fungsi estetika memberi keindahan juga kebenaran dan kesucian sehingga masyarakat merasakan keindahan dalam mengatur laku hidup yang dituangkan dalam sarana dan pelaksanaan upacara. Fungsi social ditunjukkan oleh masyarakat yang secara gotong royong bahu membahu memuat upakara dan melaksanakannya dengan konsep ngayah.
\end{abstract}

Kata Kunci: Fungsi; Upacara Ngenteg Linggih 


\section{Introduction}

The ceremony in Hinduism is an activity related to a belief in God / Ida Sang Hyang Widhi Wasa and its manifestations. In particular, in Hinduism, the implementation of the ceremony is called a yajña. Yajna is sacred worship that is performed on certain days and adults (Surayin, 2004:3)

Dewa Yajña is a sincere offering to Ida Sang Hyang Widhi Wasa and all its manifestations. Dewa comes from the word Div which means light or holy light. Like the light that comes from the sun, so the Gods are the source of the creator, Sang Hyang Widhi Wasa (Wijayananda, 2004:10)

Devas as a manifestation of God have different characteristics and characteristics such as Visnu, Brahma, Iswara and others who have different powers, but the Gods are still sourced from God. Thus, the worship of the Implementation of Dewa Yajña is due to a debt to Sang Hyang Widhi Wasa who has created the universe and its contents including humans. Humans can take advantage of the contents of this nature with everything sourced and created by God. This debt is called Dewa Rna. On that basis, Hindus are obliged to devote themselves to Sang Hyang Widhi by making offerings in the form of Dewa Yajna.

The performance of Lord Yajña can take many forms. The activities of daily life can be transformed into Yajña by carrying out all activities based on awareness, sincerity, full responsibility and making these activities an offering to Ida Sang Hyang Widhi Wasa as said

yajñärthāt karmano 'nyatra

loko 'yam karma-bandhanah,

tad-artham karma kaunteya

mukta-sangah samācara.

Translation:

From the purpose of doing that yajña, the world is bound by the law of karma, therefore, O Arjuna, work selflessly, without personal gain, O Kuntiputra (Pudja, 2013:84)

The performance of Lord Yajña has the following objectives:

1. To express gratitude to God.

2. As an expression of devotion to Ida Sang Hyang Widhi Wasa.

3. As a way to ask for protection and warrants and requests for forgiveness for all sins.

4. As an embodiment of Vedic teachings.

Basically the Yajña aims to pay off debt (Rna), namely debt of gratitude and debt to God (Sang Hyang Widhi Wasa). Because of Yajña's blessing to Ida Sang Hyang Widhi Wasa, the universe and its contents were created. The gods are the light or rays of God (Ida Sang Hyang Widhi Wasa) who are empowered to protect the universe and its contents. Therefore the Devas must be satisfied with the performance of the yajñas prescribed in the Vedas. Furthermore, there are various types of Yajña that humans do to achieve their feelings or wishes, for example

An incidental yajña ceremony is the holding of a yajña which is carried out incidentally according to the needs of the community, such as carrying out ceremonies for cleansing the universe such as Rsi Gana and others. Ceremonies associated with holy places such as Melaspas, Pujawali, Piodalan.

According to Wikarman (1998:10) one of the yajña ceremonies for a holy building (temple) that has just been built and has been pelaspas, will be accompanied by the Ngenteg Linggih ceremony. The Ngenteg Linggih ceremony is to instill Ida Sang Hyang Widhi Wasa so that he will sit eternally (stable, lasting). In other words, Ngenteg Linggih is to make the earth or in a smaller context, namely a temple to become a place for Ida Sang Hyang Widi Wasa to gather. There are two types of Ngenteg Linggih ceremonies, namely:

1. Ngenteg Linggih mamungkah, in the form of the Ngenteg Linggih ceremony when a new temple was built and the ceremony had never been held. 
2. Ngenteg Linggih Mupuk meat is a Ngenteg Linggih ceremony which is held every 10-15 years by holding a new mendem pedagingan ceremony to revitalize the temple that had been established decades earlier.

On the Ngenteg Linggih ceremony will be accompanied by caru rsi gana, offerings for the segjeg, as well as for kerti. Banten bagia also kerti is offering which means behavior that gets happy results. Penyegjeg is offering so that the universe is upright. The Banten-banten is a symbol of the universe which at the end of the ceremony will be planted into the earth.

The Ngenteg Linggih ceremony through its ceremonies and ceremonies is very beautiful because it represents the beauty of the universe in the concepts of siwam (holiness), satyam (truth), and sundaram (beauty). In caru rsigana there will be a symbol of the nawasangga gods written on the nagasari leaves and the use of flower and urip colors according to the sensing. Likewise, the offerings for Bagia Pulakerti and Penyegjeg will be equipped with plants according to the identification. Also equipped with a small umbrella according to the color of Dewata Nawa Sangga. Apart from the ceremony, the series of ceremonies also have a function, starting from mangun hayu, mahingkup, ngaremekin, makebat daun, ngebek, and nyenuk.

The Ngenteg Linggih ceremony which is studied from its research function is in Pejaten, Tabanan. This was based on the fact that in Pejaten Village, in the implementation of the ceremony, the Hindus still practiced conceptualizing by making ceremonies together even though the residents made their living in the tile, ceramic, brick and terracotta industries. In addition, the implementation of the ceremony, especially in the ceremony in the village, does not count tumpeng. This is peculiarity as a tradition of ceremonies and there is a banten pemepekan as a symbol of the urip which amounts to nine in nine tamas and in the middle it is symbolized as a teacher with the most complete counterpart. This research was conducted with the aim of examining the function of the Ngenteg Linggih Ceremony in Pejaten, Tabanan. Assessed about religious, ethical, aesthetic, and social functions

\section{Method}

The function of Ngenteg Linggih ceremony in Pejaten, Tabanan, used in this research is qualitative. According to Strauss and Corbin (2003: 4) that qualitative research is a type of research whose findings are not obtained through statistical procedures and other forms of calculation, but with examples in the form of research on a person's life, history, and behavior, as well as on the role organizations, social movements, or reciprocal relationships.

Data collection with observation, interviews, and document study. Observation is very important because it is a way of observing behavior and objects that are used or produced by society which is intended to be understood through research. Interviews aims to obtain as much information as possible from informants. Information or data obtained from informants who are positioned as key informants will greatly determine who is eligible to be the next informant so that in conducting interviews it is pursued in an open, systematic manner and in a pleasant situation. Apart from using observations and interviews, data in this study were also obtained from analyzing related documents. Data were analyzed by reduction, presentation, and conclusion, and carried out descriptively with formal and informal presentations.

\section{Result And Discussion}

The definition of function according to the Complete Indonesian Dictionary is the use of a thing, the utility and the work done (Departemen Pendidikan Nasional, 2012). According to experts, the definition of function is according to The Liang Gie in Zainal (2008), function is a group of activities belonging to the same type based on its nature, implementation or other considerations. The same perception as the definition of function according to Sutarto in Zainal (2008:22), namely function is a breakdown of tasks that are similar or closely related to each other to be carried out by a certain employee, each based on a group of similar activities according to their nature or implementation. 
Religion becomes important in human life because knowledge does not work well without religion providing the necessary means of adaptation. Functional theory views religion in relation to the experiential aspect of transcending a number of events involving beliefs and responses to something different beyond human reach. The function of religion is to open horizons about the outside world that the human mind cannot reach. Ritual activities allow human contact with the outer reaches of being seen as the giver of salvation.

\section{Religious Functions}

Religion is a form of belief that arises beyond human ability which consists of basic elements, namely: belief systems, ritual and ceremonial systems, religious emotions, ritual equipment, ceremonies and religious communities (Cudamani, 1993:41). Based on the description above, religion is the existence of a belief that arises in humans about the existence of an extraordinary power beyond human ability so that humans show a response (do religious) in their lives.

For Hindus all deeds, karma, good and noble works are a yajña. In beryajña it must be based on a clean heart and sincere sincerity, because it is presented to Sang Hyang Widhi with all of His manifestations. Without yajñas or holy sacrifices that are done sincerely, harmony and balance in life will not be achieved.

This is confirmed in the Bhagavadgītā III.11 it is stated:

devān bhāvayatānena

te devā bhāvayantu vah,

prasparam bhāvayantah

śreyah param avāpsyatha.

Translation:

The existence of the gods is because of this, I hope they make you that way, by giving each other you will get the most virtue (Pudja, 2013:85).

The universe and human nature are made of the same five basic ingredients: water (liquid), wind (air), fire (light), Earth (solid matter), and ether (space, void) - the panca maha bhuta, which exist in form two opposites but need or complement each other (Rwa Bhineda) such as Hot and cold, Black and White, and so on. Balance can be created or chaos can be corrected through work and ceremony (yajña) to God and all of His manifestations. In doing this there are various provisions that must be obeyed. The main stipulations are the three behaviors that bring liberation (tri kaya parisudha): think, say and do the right thing. Love for all creatures (tat twam asi); and flexibility to adapt to place, time and conditions (desa, kala, patra).

Yajña (ceremony) as a Balinese way of acknowledging the greatness of God and expressing love and devotion to Him is one of the real forms of implementing the Hindu way of life in Bali. There are hundreds of types of yajña, according to their function the yajña can be grouped into three, namely: yajña as offerings and requests (God, Ancestor, Rsi), yajña for universal balance (caru, tawur), yajña as mental and spiritual cleansing or treatment (melukat).

The function of the panyegjeg offering as one of the offerings in the Ngenteg Linggih Ceremony is a form or symbol of the universe which means planting yasa kerti deeds (karma) which results in happiness of life satisfaction in birth and happiness. Banten panyegjeg is one part of the various types of offerings used in the Ngenteg Linggih ceremony. Thus the function of offering panyegjeg in this ceremony is a manifestation of human devotion to God which is formed in such a way, which contains all of God's creation itself which is symbolized like a human body or God's body which is likened to a human being. Because in general, we cannot fully imagine the forms, colors of Sang Hyang Widhi Wasa, so that what humans present to Ida Sang Hyang Widhi Wasa, people only imagine that they are like humans themselves. Of the various types of offerings used in the Ngenteg Linggih Ceremony, Banten panyegjeg is symbolized by the form of God as human. 
This symbolization can be justified because in essence what is offered is part of Sang Hyang Widhi Wasa, as expressed in the following Bhagavadgita IX.16.

aham kratur aham yajñah

svadhāham ahai் aușadham,

mantro 'ham aham evājyam

aham agnir aham hutam.

Translation:

I am a kratuh offering, I am a sacrifice (offering), I am an offering to the ancestors (svadhā), I am a medicinal ingredient, I am a mantra, I am pure butter too, I am fire and I am an offering (huta) (Pudja, 2013:232).

Ceremonial work, prayer is Me. The ingredients for potions are I, the Holy Word, incense, incense is I, and fire and devotional fire are I. The offering and the purpose of the offering are ultimately God Himself. Banten panyegjeg is a form of offering to Ida Sang Hyang Widhi Wasa, as an expression of human gratitude to God as the creator. The form, content, and ornaments that exist are one way of showing the devotion of the people who try to arrange the best for God Himself. This form is a development of the basic concept of the conditions of an offering because in principle the terms of the offering are in accordance with Bhagavadgita IX.26 which states that.

\section{patraim pușpam phalaim toyam}

yo me bhaktyā prayacchati,

tad aham bhakty-wagesrtam

aśnāmi prayatātmanah.

Translation:

Anyone who with prostration and devotional service to Me offers a leaf, a flower, a fruit, a sip of water, I accept as devotional offerings from a person with a pure heart (Pudja, 2013:239).

Any offering must be based on sincerity and purity of heart. Because sincerity will measure the success of a ceremony. Avoiding all activities aimed only at fulfilling one's own passions and desires is the same as carrying out all activities aimed at worshiping Ida Sang Hyang Widhi Wasa. As contained in Bhagavadgita IX.27 it is stated that.

yat karoși yad aśnāsi

yaj juhoși dadāsi yat,

yat tapasyasi kaunteya

tat kuruṣva mad-arpañam.

Translation:

Whatever you do, you eat, you offer, you give, and whatever self-discipline you do, do it, O Arjuna as devotional service to Me (Pudja, 2013:240).

\section{Ethics Function}

Ethics are customs, namely norms adhered to by certain groups, groups or communities, both regarding good deeds and bad deeds. Therefore, humans must be able to regulate their lives in their behavior, because with ethics or morals a good and harmonious relationship between individuals, groups, groups and society will be realized. Ethics in Hinduism is called morality, which means good and noble deeds. Ethics is a guideline that needs to be implemented to realize good and noble behavior, as in the Sārasamuccaya 160 is explained:

șilam pradhānam ̇ puruṣe tadyașyeha prānasyati

na tasya jūìitenārtho duhșilam kinprayojanam.

Cila ktikang pradhāna ring dadi wwang, hana prawrttining dadi wwang duccila, aparan ta prayojananika ring hurip, wibhawa ring, kaprajñan ring, apan wyartha ika kabeh, yan tan hana silatukti.

Translation: 
Immoral that is the most important (absolute basis) in the incarnation as a human being, if there is behavior (action) of the incarnation as a human being is immoral, what does that person mean by his life, with power, with wisdom, because everything is vain (life, power, and wisdom) if there is no moral application to action (practice immoral) (Kajeng, 1999:132).

The function of ethics is the manifestation or expression of faith in God in the form of behavior. The regulation of behavior is based on faith and belief which is formulated in religious rules in the form of moral and ethical commands. Guided by these religious principles, adherents of religion live and act (Harjana, 1993:13-14)

Thus morality has an important position in behavior, because someone who has morals can be seen from the way of thinking, saying and doing which in Hinduism is called Tri Kaya. This Tri Kaya (thinking, saying, and doing) can only be called Tri Kaya Parisudha when it can be purified. Tri Kaya Parisudha are three noble (good) behavior. The three actions include: Manacika, namely thinking good and pure, Wacika which means saying what is good and right, and Kayika which means behaving well and right. As stated in the Sarasamuccaya sloka 77, it says:

Kāyena manasā vācā yadabhiksnam nișevyate,

Tadevāpaharatyenam tasmāt kalyānamācaret.

Apan ikang kinatahwan ikang wwang, the school, I remember it, the funny thing, yes, umalap ikang wwang, jênêk katahwanirika wih, ripe ikang hayu or ngabhyas an, ring kaya, wāk, manah.

Translation:

For what makes a person known is his deeds, thoughts, sayings; that's what really attracts people's attention, To know someone's personality; therefore let it be What is good is always accustomed to things, words and thoughts (Kajeng, 1999:68).

In carrying out the Ngenteg Linggih ceremony, ethics must be carried out, this is in accordance with what is contained in the Sesana Sarathi Banten, that in carrying out the ceremony, namely matetuasan, nyamuh, and metanding, including nyorohang offerings, a Sarathi or Tapini who leads the ceremony can guide the pengayah to always maintain ethics. Like Sarathi banten, which was previously called Ritwija, a Sarathi is the first to be responsible for preparing the ceremony form and carrying out the Panca Yajña ceremony fulfilled in terms of the ceremony. When a Sarathi prepares a ceremony he must also understand the structure of the ceremony and the basic understanding associated with the Panca Yajña. The following will describe sarathi as follows.

a. Sarathi banten is a spiritual profession for those who dedicate themselves and their lives to the making, composing and meaning of religious practices through symbols which are then commonly called upakara or offerings or offerings.

b. Banten which is made must be based on sincere sincerity and good sesana so as to increase the meaning and meaning of a ceremony

c. Sarathi banten are the spearhead of all ceremony activities that are held.

1) Continuously striving to maintain self-purity based on the teachings of Tri Karya Parisudha

2) Obliged to perform worship to Dewi Tapini

3) Accompanying and serving officers pemuput karya

4) Prepare, organize offerings in the implementation of the yajña ceremony

5) Avoid conflict and must refer to the Dharma Sidhyarta concept, namely:

Iksa = have a good goal

Sakti $=$ strength

Desa $=$ place

Kala $=$ time

Tattwa $=$ philosophy / foundation of belief 
d. Referring to legal references, namely Sruti, Smrti, Sila, Acara, and Atmanastuti

e. Socializing the Tri Manggalaning Yajña concept

f. Sesana sarathi banten

1) How to dress: white, colored, clean and tidy kebaya, wearing a senteng, and a kamen

2) Maternal appearance, hair tied / in a bun

3) Sarathi's attitude offered

a) pray first

b) obliged to respect the Manggala Yajña

c) ready physically and psychologically

d) have sraddha and bhakti

\section{Aesthetic Function}

Hindus in their daily life almost never do not perform yajña, especially the yajña ceremony. It is believed by Hindus that anything done with a sense of sincerity and without expecting a result is said to be a yajña. In performing a yajña, especially in Bali the understanding of the yajña is limited to ceremonies and ceremonies. However, in reality yajña is to serve sincerely to make sacrifices for a noble cause.

The beauty of a man-made work can give a sense of pleasure and satisfaction with the enjoyment of a beautiful taste which includes several basic elements in aesthetics, namely appearance, weight, and appearance. The content or weight of an artistic event is not only seen, but also includes what can be felt or lived as the meaning of the art form. The appearance refers to the understanding of how art is presented or presented to the audience (Djelantik, 1999:15)

Yajña or the yajña ceremony in its implementation varies from region to region according to the provisions of each place, namely village, kala, and patra, but has the same purpose. This is emphasized in Mānava Dharmaśāstra VII.10 (Pudja \& Sudharta, 2004:289) that the application of Hindu teachings including yajña ceremonies to run successfully (Dharma Sidhyartha) must be based on five considerations, namely Iksa which means the views or ideals of the community, Sakti means ability, Desa means local regulations that are adhered to. a society, Kala means time, and Tattwa means the essence of Vedic truth (Wiana, 2004:39-40). The Ngenteg Linggih ceremony is a tradition and culture inspired by Hinduism to satisfy the physical and spiritual needs of the community so that this ceremony is felt to be very important for that community.

Hindus in their daily life almost never fail to perform yajña, especially the yajña ceremony. It is believed by Hindus that anything done with a sense of sincerity and without expecting a result is said to be a yajña. In performing a yajña, especially in Bali the understanding of the yajña is limited to ceremonies and ceremonies. But actually yajña is to serve sincerely to make sacrifices for a noble cause.

According to Mortimer Adler, beauty is a property of things that gives us the uninterested pleasure that can be obtained solely from thinking or seeing individual objects as they really are. This opinion is very appropriate to be used to explain the aesthetic function contained in the Ngenreg Linggih ceremony, in which the beauty in an object (object) has a very close relationship with the human ability to judge a work of art. Humans can think or see a beauty if they feel pleasure in the object they observe. Likewise, the Ngenteg Linggih ceremony has an aesthetic value, which is it looks very beautiful if someone who judges it can feel pleasure that has no interest in him (the observer) by thinking or seeing the object (Gie, 1983:13). Thus a person who only sees or thinks only, and can give pleasure to the observer so that a beautiful feeling appears in himself and gives an assessment of the object he sees.

Besides referring to the opinion of Mortimer Adler, also used Brown's opinion. Brown explained that the concept of function involves a structure consisting of a set of relationships between unit entities, the continuity of the structure is maintained or preserved by the life process embodied by the activity of the units contained therein (Ningrat, 2006:76). The 
relevance of Brown's view in this research is related to the implementation of the Ngenteg Linggih ceremony in Pejaten village.

The implementation of the Ngenteg Linggih ceremony by means of ceremonies or upakara (banten) also implicitly contains artistic values (aesthetics). The manifestation of the aesthetic values (beauty) is a form of expression of the people as a seriousness in carrying out ritual activities in the ceremony. All religious activities carried out by Hindus actually have a very high beauty value, among others, in the Ngenteg Linggih ceremony there are various arts such as: percussion (gambelan), sound art (kidung) and dance (Rejang, Sidakarya Mask), and Weak puppets. In the implementation of the Ngenteg Linggih ceremony, the right kidung to use is the Wargasari Kidung, Bramara Ngisep Sari. One of the offerings in the Ngenteg Linggih Ceremony which is placed in the solar resignation is the Dewa Dewi offering and the visible form of beauty is in the form of two phallus which are arranged based on the composition, namely banyan leaves and Uang Kepeng and at the end filled with tipat Lingga. In addition, beauty can also be seen in mereringgitan, among others, in the area of offerings, also kerti, offerings of chess, bebangkit, return, sekar gardens so that these offerings look beautiful.

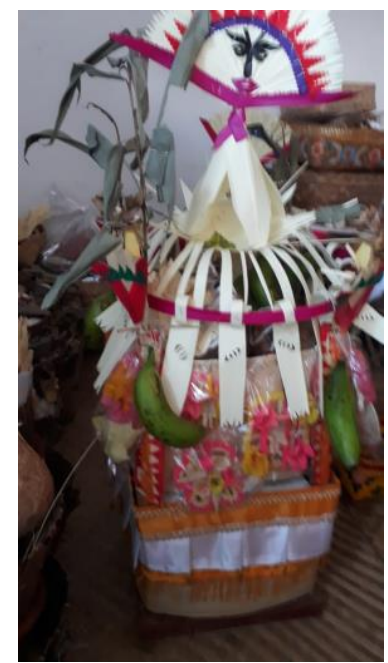

Image 1

Banten Bebangkit

(Doc: Puspa and Saitya, 2020)

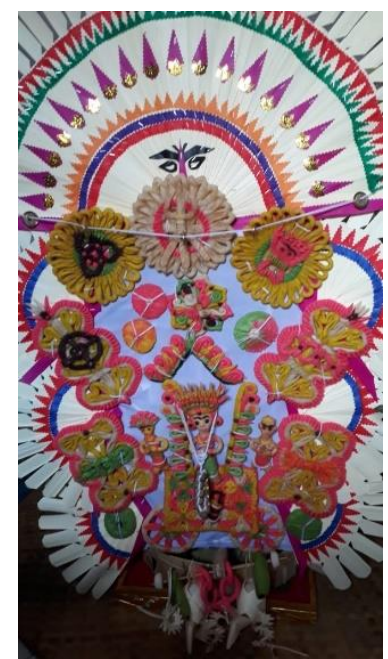

Image 2

Banten Pulagembal

(Doc: Puspa and Saitya, 2020)

It is related to pouring out taste and feeling is related to expression in expressing something. If it is relevant to aesthetic theory in accordance with the surgical tools of this research, then in the perspective of aesthetics there are three groups of theories known as objective theory, subjective theory, and balance theory. The objective theory is adopted by Plato, Hegel, and Bernard Bosanquet which states that the characteristics that create beauty are the qualities or qualities that have been attached to the beautiful object in question, regardless of the person observing them. Meanwhile, the subjective theory adopted by Henry Dome, Earl of Shaftesbury (Lord Ashley), and Edmund Burke argues that the characteristics that cause beauty in an object actually do not exist.

Based on the in-depth study of the researcher and considering various existing aesthetic theories, the Ceremony research Ngenteg LinggihThis is more precisely supported by Wladyslaw Tatarkiewicz's aesthetic theory called the "Great Theory of Beauty" or the theory of balance. Wladyslaw Tatarkiewicz said that beauty consists of a balance of parts or rather consisting of size, equation, and the number of parts and their relationships to one another (Gie, 1983:51). In the means of the ceremony / offering the composition of each material or means is calculated in relation to the balance between the amount, size and equality as well as their relationship to one another. Considering the offering of Dewa Dewi as one of the offerings for 
the Ngenteg Linggih Ceremony can be seen in terms of its shape consisting of two upright phallus yoni which are arranged by means of leaves, flowers, and Uang Kepeng,

\section{Social Functions}

According to Wiana (2002:172) to hold a yajna ceremony, everyone can take a role according to their function and profession (swadharma or their respective jobs). It is not only pinandita or sarathi that can play a role in a yajña ceremony.

The Ngenteg Linggih ceremony has the following social functions.

a. Can unite the community because they take turns and are responsible for presenting all forms of infrastructure at the preparation, implementation, and end of the ceremony.

b. Symbolically, together in the ceremony, it can eliminate the sense of ego that is in humans, because they take turns in an orderly manner and queue to carry out their duties and obligations. Making offerings, menabuh, mekidung and so on.

The social function contained in the making of the ceremony at the Ngenteg Linggih ceremony made by the people of Pejaten Village is to educate community members to help each other and help each other and live side by side in harmony. Because someone is not able to avoid the attachments and dependence of others. Assistance and assistance in living together is an effort to achieve Jagathita, namely happiness and prosperity in the world. Including in the provision of materials, to the manufacturing process and others, if there is no social interaction between the entire community there will never be a beautiful form and in the form of offerings in the Ngenteg Linggih ceremony.

Upacara Ngenteg Linggih also has a social function, namely how much influence, in this case, social institutions (family, community) in the implementation process and how long (time) can be used as a vehicle for social interaction by the supporting community. Sociocultural, the implementation of religious ceremonies involves community activities. The social function with regard to ceremonies or rituals, namely the Ngenteg Linggih ceremony using the upakara means is a function of social solidarity because in the manufacturing process it involves people in the community. The making of ceremonies and ceremonies is carried out by the Pejaten people, there is no buying offerings. As we know that humans apart from being individual beings, also as a social being who in his life cannot live alone without the help of others. Man can only live in the best possible way. The human body will only have meaning, if he lives with other humans in society. As described in the Sārasamuccaya 4 book, being a human being is very important and noble because it has three elements in the form of Tri Pramana, namely Sabda, Bayu, and Idep. Word (voice) is the ability to speak as a means of communication. Bayu (strength) is the power to carry out all activities, and Idep (mind) is the ability to choose and sort out what is good and bad or right and wrong. These three virtues are not the same for each individual. Realizing his shortcomings, humans need help and give help to others.

As is the case in use offer bagia as well as kerti, segjegin the Ngenteg Linggih ceremony which is evident in the community there must be in the ceremony. Philosophically, it is a means (upakara) in the Ngenteg Linggih ceremony which is placed on the asagan in front of the pelinggih which will eventually be bent and planted to be returned to the land and concretely in the process of making it supported by a positive behavior.

The implementation of the Yajña ceremony (Panca Yajña) including the Ngenteg Linggih ceremony has a purpose and function as a vehicle for improving social life. This can be seen from the process of making offerings at the Ngenteg Linggih ceremony, where in preparing the materials (the means of the ceremony) there has been a social interaction between the yajña implementers (Yajamana Karya) with sulinggih (ceremony leaders) and sarathi banten (people who prepare and make offerings). Likewise, the relationship between families becomes harmonious because there is always social interaction, starting from planning, preparing the means of the ceremony to the completion of the ceremony (offer). In maintaining 
a harmonious relationship in the family and society, every individual has a necessity to meet his needs in life that cannot be ignored.

The social function can also be seen in the form of the procession of the ceremony Ngenteg Linggih starting from planning, implementing ngayah in making ceremonies and ceremonies, and in carrying out the ceremonies which of course cannot be done alone. As a social being, a person will always be in touch with other people. Especially in preparing the Ngenteg Linggih ceremony which requires a lot of people so that the spirit of solidarity can be cultivated and the management of the ceremony can be carried out with reliable human resources. In this social function, the community's involvement in this case is close family, customary manners, and sarati offerings so as to create a sense of togetherness and mutual cooperation. Among the community members, in the success of the activity, in this case the Ngenteg Linggih ceremony (interview with I Nyoman Suweca, July 20, 2020).

\section{Conclusion}

The Ngenteg Linggih ceremony has a religious function, namely to strengthen faith through the implementation of the ceremony, an ethical function that can be followed by the community in carrying out and carrying out ceremonies in accordance with the sarathi sesana, aesthetic functions that give a touch of beauty to the shape and color of the ceremony, and social functions that can memorialize the community because it can be jointly for solidarity in building a ceremony where there is no buying, but everything is done in the concept of ngayah.

\section{References}

Cudamani. (1993). Pengantar Agama Hindu. Jakarta: Hanuman Sakti.

Departemen Pendidikan Nasional. (2012). Kamus Besar Bahasa Indonesia Pusat Bahasa.

Jakarta: PT Gramedia Pustaka Utama.

Djelantik. (1999). Estetika sebuah Pengantar. Bandung: Masyarakat Seni Pertunjukan Indonesia.

Gie, T. L. (1983). Garis Besar Estetik (Filsafat Keindahan). Yogyakarta: Super Sukses.

Harjana. (1993). Penghayatan Agama: Yang Otentik dan Tidak Otentik. Yogyakarta: Kanisius.

Kajeng, I. N. dkk. (1999). Sārasamuccaya dengan Teks Bahasa Sanskerta dan Jawa Kuna. Surabaya: Pāramita.

Ningrat, J. A. (2006). Banten Panjang Ilang Kajian Bentuk Fungsi Makna. Institut Hindu Dharma Negeri Denpasar.

Pudja, G. (2013). Bhagavadgītā (Pañcama Veda). Surabaya: Pāramita.

Pudja, G., \& Sudharta, T. R. (2004). Mānava Dharmaśāstra (Manu Dharmaśāstra) atau Veda Smrti Compendium Hukum Hindu. Surabaya: Pāramita.

Strauss, A., \& Corbin, J. (2003). Dasar-Dasar Penelitian Kualitatif. Yogyakarta: Pustaka Pelajar.

Surayin, I. A. (2004). Melangkah ke Persiapan Upacara. Denpasar: Upada Sastra

Wiana, I. K. (2002). Mengapa Bali Disebut Bali. Surabaya: Pāramita.

Wiana, I. K. (2004). Makna Upacara Yajña dalam Agama Hindu II. Surabaya: Pāramita.

Wijayananda, M. J. (2004). Makna Filosofis Upacara dan Upakara. Surabaya: Pāramita.

Wikarman, I. N. S. (1998). Mlaspas dan Ngenteg Linggih. Surabaya: Pāramita.

Zainal, N. H. (2008). Analisis Kesesuaian Tugas Pokok dan Fungsi dengan Kompetensi Pegawai pada Sekretariat Pemerintah Kota Makassar. Universitas Hasanuddin. 